\title{
18. 実験的脳動脈瘤
}

\author{
半田肇橋本信夫永田泉 \\ (京都大学医学部脳神経外科) \\ 挾間 章忠 \\ (滋贺医科大学病理)
}

\section{はじめに}

脳動脈瘤の動物モデルを確立することは脳動脈瘤の病 態, 治療を解決する上できわめて重要と思われる。乙か し，動物で脳動脈瘤を認めたといら報告はチンパンジー の数例の報告のみで, 実験的にも多くの試みがなされて いるが, 囊状動脈瘤（saccular aneurysm）を誘発乙得た という報告は未だない. Hassler ${ }^{2)}$ はウサギの一側額動脈 結柇で動脈瘤の初期病像と思われる所見を得たと報告し ているが, これは光顕レベルではじめて認められる程度 のものである。

われわれはラットを用いて，七トの脳動脈瘤と全く類 似した囊状動脈瘤を高頻度に誘発させるのに成功したの

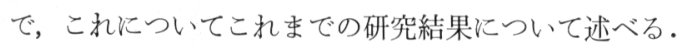

\section{実験方法ならびに結果}

1. 万法は成熟ラットに一側頝動脈結森, 一側腎臓摘 出と DOCA, 食塩を負荷して高血圧症を作成し, さら飞 $\beta$-aminopropionitrile (BAPN) を投与する. $\beta$-aminopropionitrile は lathyrogen の一種で collagen 抢よびelastin の架橋結合を特異的に阻害し, 全身の結合組織を脆弱化 させることが知られている。この成熟ラット，高血圧 症, BAPN 投与の三者併用の意義は, 元々われわ机がこ の研究をはじめた時の仮説, つまり動物の血管を何らか の方法で脆弱化させ，その動物の脳血管に强い hemodynamic stress を負荷すれば, locus minoris resistentiae の 部が膨隆，破綻するであるらという考光に基づいて行っ たものである。

しかし, 現在では DOCA の代りに両側腎動脈の posterior branch の ligation t行い, さら飞 BAPN の投与 を行わなくても，頻度は低いが総動脈瘤を誘発させうる ことが判明している3).

2. 成熟ラットを用いる理由は, 上述の操作を， 3 週 齢， 4 週秢， 6 週龄， 6 カ月齢のラットを用いて行った
ところ, 合計55例中 6 例飞脳動脈瘤の発生を認めたが, 上述の操作付耐克, 脳動脈瘤の発生も高頻度であったの は成熟ラットであることが分ったからである4)(第 1 表).

表 1

\begin{tabular}{|c|c|c|c|}
\hline Group & 例 数 & 脳動脈瘤 & 最高血封 \\
\hline I. 3 週秢 & 20 & 1 & $220 \pm 2$ \\
\hline II. 4 週齿 & 20 & 2 & $224 \pm 5$ \\
\hline III. 6 週粭 & 10 & 1 & $210 \pm 6$ \\
\hline N. 6 力月齢 & 5 & 2 & $216 \pm 15$ \\
\hline
\end{tabular}

3. 以上のような要因を負荷すると, 数週〜数力月後 飞突然死亡, 㴿死の状態, 四肢麻痺あるいは activity の 低下などの神経症状を呈してくる，開頭すると，小さ な前交通動脈瘤が破裂してクモ膜下出血, さらに basal cistern 飞凝血塊を有していたり，血管を剝離すると巨 大な囊状動脈瘤を認めたり(第 1 図),ささらにさな動 脈瘤で明らかに血管分枝部から発生していたり(第 2 図)，また前交通動脈全体が膨化した形のものも認めら れる。

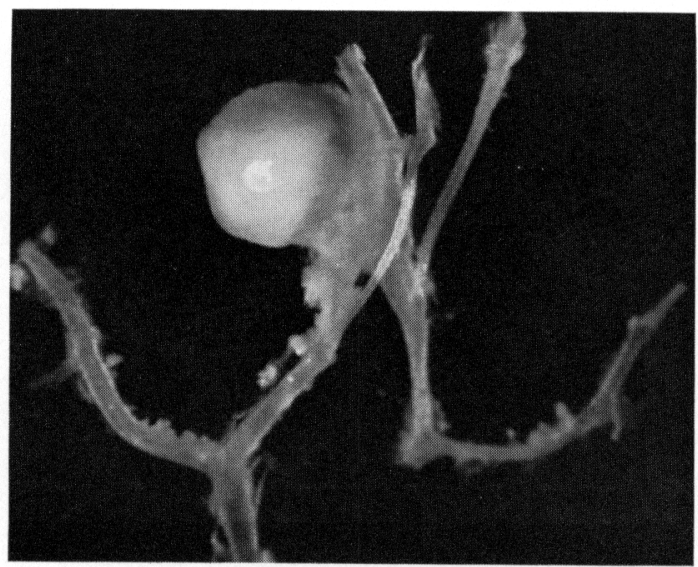

図 1 前交通動脈に発生した巨大な脳動脈瘤 


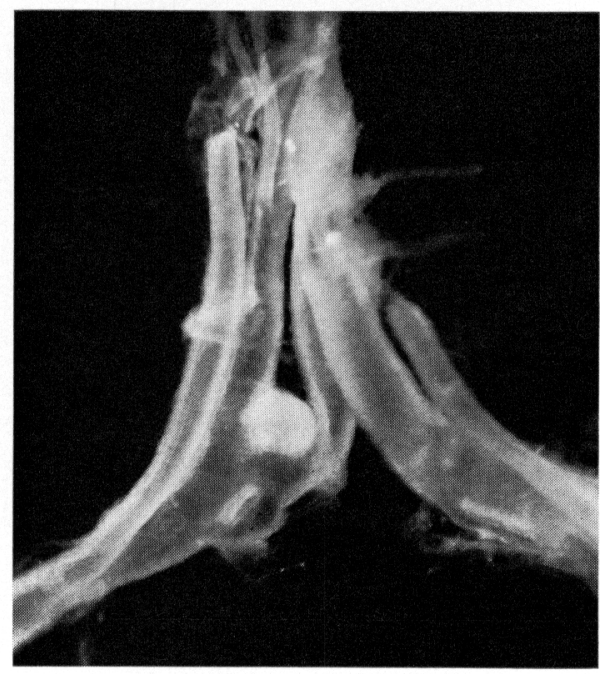

図 2 血管分枝部から発生した小さな前交通動脈瘤

これら動脈瘤発生頻度は実験開始後約 5 力月間に30例 中11例，1/3以上の頻度である。

4. 組織学的には，血管分枝部 apex に発生した動脈 瘤では, 動脈瘤壁は血管の三層構造を失い, 主に結合組 織よりなっている.拡大してみると, 内弾性板は動脈瘤 開口部で消失，中膜筋層も同様の変化を示している。 た dome に小さな blebがあり，壁はきわめて薄く，末 さに破裂直前の状態のものもある.大きな動脈瘤では, ヒトの場合と同様に血栓化傾向を認めるが，ある例では 動脈瘤内腔は半分以上血栓化し, 残った内腔から破裂 し, 死亡した. さらに血栓, 器質化が進んだ例では, 血 栓は器質化し, 動脈瘤壁には fibroblast が多数増生して いる。

このように実験的脳動脈瘤は組織学的にもとトの動脈 瘤に類似しその運命もヒトの場合と殆んど同様である。

5. 脳動脈瘤誘発条件 (第 2 表)

a. 実験的高血压症と BAPN 投与の多行い, 頝動脈 結禁を行わない群の Willis 動脈輪を久ると, Willis 動 脈輪は symmetrical で, 両側の $\mathrm{P}_{1}$ 部は非常に細い。 このよらな群では脳動脈瘤は発生しない.

b. 実験的高血圧症に BAPN 投与, さらに一側頝動脈 結紮を加えると, 結紮側半球は前交通動脈扣よび結柇側 $\mathrm{P}_{1}$ 部を介して collateral circulation が得られ, 結禁側 $\mathrm{P}_{1}$ 部は例外なく対側に比してその径を増している。こ のような群では, 前交通動脈部なたは結紮側 $\mathrm{P}_{1}$ 部に動 脈瘤の発生を認める。
表 2 実験的脳動脈瘤発生部位

\begin{tabular}{|c|c|c|c|c|}
\hline Group & 例数 & 最高血圧 & $\begin{array}{c}\text { Ac-A com } \\
\text { 動脈瘤 }\end{array}$ & $\begin{array}{c}\text { Willis 輪 } \\
\text { 後半部動脈瘤 }\end{array}$ \\
\hline I & 23 & $192 \pm 3$ & 0 & 0 \\
\hline II & 22 & $195 \pm 5$ & 9 & $4^{*}$ \\
\hline III & 23 & $194 \pm 3$ & 0 & 8 \\
\hline \multicolumn{5}{|c|}{ 第 1 群 } \\
\hline \multicolumn{2}{|c|}{ 第 2 群 } & \multicolumn{3}{|c|}{ 高血圧症＋BAPN＋一側頝動脈結柴 } \\
\hline $\begin{array}{l}\text { 第 } \\
*\end{array}$ & $\begin{array}{l}\text { 羊 } \\
\text { 然側O }\end{array}$ & \multicolumn{3}{|c|}{ 高血圧症＋BAPN＋両側頝動脈結杽 } \\
\hline
\end{tabular}

3. 実際的高血圧症に BAPN 投与, さらに両側頝動 脈結紮を行うと, 雨側の $\mathrm{P}_{1}$ 部が拡大し, 脳底動脈も 桩張蛇行し, 動脈瘤は posterior circulation にの夕発生 し, anterior circulation には発生しない.

以上の結果は，頝動脈結紮は本実験では動脈瘤誘発に 必須の条件で，動脈瘤発生部位は頝動脈結紮によって生 じる際の anastomotic channel となる部位, つまりもっ とも hemodynamic stressを受けると考えられる部位で あることを示している。

この結論がまず間違いないことは次の事実によっても 確かめられた。つまり，その後の実験に拈いて，高血压 症に BAPN 投与, さらに一側頝動脈結紮群で, 時に結 禁反対側の carotid bifurcation あるいは olfactory artery 起始部に動脈瘤を認める例があったが，これらも例外な く hemodynamic stress のかかると思われる部位であっ た。

6. hemodynamic stress の重要性

ヒトの前交通動脈瘤に括いては $\mathrm{A}_{1}$ 部の asymmetry を 認める場合が多く，この場合には一側の $A_{1}$ から両側の $\mathrm{A}_{2}$ portion が潅流されるため前交通動脈部に stress が加 わり，動脈瘤が発生し易い。換言すれば, hemodynamic stress が動脈瘤増大に関与しているであろらということ は多くの人が認めている.本実験に拈いても，一側頝動 脈結禁により前交通動脈を介して cross circulation が生 じるため，この部位に強い hemodynamic stress が加わ り，動脈瘤が発生すると考えられる。したがって，ヒト の脳動脈瘤の発生にも hemodynamic stress の大きいこ とが考壳られる。

\section{7. 脳動脈瘤の follow-up}

小動物の脳血管撮影を行い，その動物を生かして，実 験を継続させる方法は未だ報告されていない。われわ れはラットの総額動脈または, 頝動脈より外径 $0.7 \mathrm{~mm}$ の Teflon tube catheter を挿入し，血管撮影を行うと， 
Willis 動脈輪前半部, 一側頝動脈結紫例では脳底動脈, 結紮側 $\mathrm{P}_{1}$ 部がかなり明瞭に造影され, ある程度の大き さを有する動脈瘤であれば，その確認が比較的容易にで さることが分った。この方法により，雨側頝動脈結柇側 の血管撮影で, 拡大, 蛇行した脳底動脈の先端に血栓化 が起っている動脈瘤が認められ，3週間後再び血管撮影 を行らと, その動脈溜がその開口部周辺の一部を残し, 他は薄いstain として造影され, 前回のものに比し動脈 瘤径が拡大していることを認めた。また別の例で前交通 動脈瘤も生前血管撮影で証明し，共に剖検で巨大動脈瘤 であった。

\section{8. 動脈熘の走查電顕像 ${ }^{3)}$}

ヒトの脳動脈瘤を用いた病理学的研究においては, 新 鮮な標本とくに動脈溜茥部を含めた material を入手す ることはきわめて困難である。事央走查電顕を用いた検 討は余りなされていない.

動物モデルでは動脈瘤内腔より血管側をみた走查電䫓 像を得ることも可能であり, endothelial cell に白血球, 血小板が付着していた。ささらに初期病変, 大型の動脈 瘤, hemodynamic stress の加わる部の血管内皮, 反対側 の血管内腔など夫々有意な所見が得られた。たとえば小 動脈瘤内皮に crater を生じている例もあり, 白血球や 血小板が endothelial cell に癒着し, 恰かも crater 内部 への侵入してゆくが如き像も見られる.ただこのよらな 所見が動脈瘤の発生, 増大に意味があるか否かは不明で あり, 現在検討中である. また動脈瘤の初期病変は血管 分枝部などに認められるが，この時期には既に内弾性板 の断裂および中膜筋層の壊死を示している.これよりさ らに初期の変化をみることにより, primary lesion は内 弾性板か, 筋層かという点も現在検討中である.

\section{Medial defect の役割}

従来血管分枝部の medial defect が動脈瘤の成因に重 要な役割を果しているのではないかと議論されてきた。 しかし, 初期病変を走查電顕でみてみると, 動脈瘤移行 部は決して単純なものでなく, endothelial cell の配列 のみだれ，ヒダ, 陥凹などを有し,より複雑なものであ ることが分った. collapse した血管から得られた従来の 情報以外に, 動物モデルのような生理的な内圧を加えた 状態で固定した標本から新たな知見が得られると考えて いる.

\section{結論}

その他の丰験結果を総合し, 現在の処, 次のような結
論を得ている1) .

1. 脳動脈瘤の発生に関し, 性差を認めていない, 卵 巣摘出を行うと, 体重, 血圧などに変化は生ずるが, 動 脈瘤の発生には効果は認めていない.

2. 脳動脈瘤誘発の最低必要条件は，一側または両側 頝動脈結禁に実験的高血圧症を併用することで，この何 れの条件が欠けても脳動脈瘤は発生しない。

3. 脳動脈瘤の発生部位は頝動脈結禁によって規定さ れる。

4. BPAN の投与は動脈瘤の誘発に必要な条件ではな いが，発生頻度を著しく増加させる。

5. 従来実験的高血圧症 の作成にDOCA-食塩高血生 症を用いてきたが，これは長期間の繁雑な管理を要する こと, 晹間膜動脈に結節性動脈周囲炎様病变を生じ易 く, 実験途中で死亡する例も少なくない. したがって, 両 側腎動脈の posterior branch を結禁し, renal infarction hypertension を扎こさせる方が動物の管理はより容易 で，高血圧の個体差も少なく，実験途中での死亡も少な く, 結果的に動脈溜誘発頻度もより高くなる.

6. この脳動脈瘤の動物モデルを用いることにより, 脳動脈熘の病理学的研究, ことに初期病変の検討が可能 であり, 動脈瘤発生のメカニズム解明にも役立つと考元 られる。

7. ヒトの脳動脈溜のすべてがこの動物モデルと同様 のメカニズムで発生するものとは思われないが，この動 物モデルが従来得られなかった種々の情報を提供し, 今 後脳動脈瘤の治療上の問題点解明にも少なからず寄与す るものと考觉られ。

\section{文献}

1) 橋本信夫 : 奏験的脳動脈溜の誘発, 日外宝 48: 667,1979

2) Hassler O: Experimental carotid ligation followed by aneurysmal formation and other morphological changes in the circle of Willis, J Neurosurg 20: 1, 1963

3) Nagata I, Handa $H$, Hashimoto $N$ et al: Experimentally induced cerebral aneurysms in rats. Part VII. Scanning electron microscopic study, Surg Neurol in press

4) Hashimoto H, Handa H, Hazama F: Experimentally induced cerebral aneurysms in rats, Surg Neurol 9: 3, 1978 